\title{
PENGEMBANGAN MODUL FISIKA BERBASIS KONTEKSTUAL MATERI DINAMIKA PARTIKEL
}

\author{
${ }^{1)}$ Mardiana, ${ }^{2)}$;Yusuf Bungkang \\ ${ }^{1)}$ SMA Negeri 5 Jayapura; mmardiana694@gmail.com \\ ${ }^{2)}$ Program Studi Magister Pendidikan IPA UNCEN; Yusufbungkang@yahoo.com
}

\begin{abstract}
This reserch is a research and development with the aim of developing Contextual-Based Physics Module on Particle Dynamic to Improve Learning Achievement of Students Grade X of SMA Negeri 5 Jayapura. The total number samples of this research is 32 students of SMA Negeri 5 Jayapura grade $X$, using one group pre-test post-test design with percentage descriptive data analysis technique to know the feasibility of the module. The research shows that: 1) the development of module with collecting information phase through bibliography research and field research, product design includes draft writing, design validating, and product design revising, and development phase consists of validating and trial, 2) the feasibility of the module compiled based on material validator resulted on average of $92 \%$ with feasible category and students response category of $88 \%$ with feasible category, 3) there is progress of achievement of studens grade $X$ with learning using contextual-based physic module in particle dynamic with n-Gain RPP1 0,52, RPP2 0,58, RPP3 0,61, and the average is 0,57 medium category, and 4) the strengths of contextual-based physics module are: simple language used, providing material with contextual illustrations and examples, and equipped with guidance manual that eases the students to do individual learning.
\end{abstract}

Keywords: Development; Development of contextual physics module; Particle Dynamic.

\begin{abstract}
ABSTRAK
Penelitian ini merupakan penelitian dan pengembangan dengan tujuan mengembangkan Modul Fisika Berbasis Kontekstual pada Partikel Dinamis untuk Meningkatkan Hasil Belajar Siswa Kelas X SMA Negeri 5 Jayapura. Jumlah sampel penelitian ini adalah 32 siswa SMA Negeri 5 Jayapura kelas X, menggunakan rancangan one group pre-test post-test dengan teknik analisis data deskriptif persentase untuk mengetahui kelayakan modul. Hasil penelitian menunjukkan bahwa: 1) pengembangan modul dengan tahap pengumpulan informasi melalui penelitian kepustakaan dan penelitian lapangan, desain produk meliputi penulisan draf, validasi desain, dan revisi desain produk, dan tahap pengembangan terdiri dari validasi dan uji coba, 2) kelayakan Modul yang disusun berdasarkan validator materi menghasilkan rata-rata 92\% dengan kategori layak dan kategori respon siswa $88 \%$ dengan kategori layak, 3) terdapat kemajuan prestasi belajar siswa kelas X dengan pembelajaran menggunakan modul fisika berbasis kontekstual dalam dinamika partikel n-Gain RPP1 0,52, RPP2 0,58, RPP3 0,61, dan rata-rata 0,57 kategori sedang, dan 4) Kelebihan modul fisika berbasis kontekstual adalah: bahasa yang digunakan sederhana, menyediakan materi dengan ilustrasi kontekstual dan contoh, serta dilengkapi dengan buku pedoman yang memudahkan siswa dalam melakukan pembelajaran individu.
\end{abstract}

Kata Kunci: Pengembangan; Pengembangan modul fisika kontekstual; Dinamis Partikel.

\section{PENDAHULUAN}

Mata pelajaran fisika merupakan

bagian dari rumpun kelompok mata pelajaran ilmu pengetahuan dan tekhnologi yang memiliki tujuan di antaranya mengembangkan pengetahuan, 
pemahaman, dan kemampuan analisis peserta didik terhadap lingkungan sekitarnya. Peserta didik diharapkan mampu memahami konsep, prinsip, hukum, dan menyusun kembali dalam bahasanya sendiri sesuai dengan tingkat kematangan dan perkembangan intelektualnya.

Memahami konsep fisika tidak hanya dengan membaca teori atau hukum hukum fisika, tetapi juga melakukan kegiatan praktik atau kegiatan mengamati suatu fenomena secara langsung. Kegiatan praktik dan mengamati suatu fenomena membantu peserta didik menjelaskan permasalahan yang ada. Keberhasilan peserta didik dalam memahami konsep fisika tidak lepas dari peran serta guru sebagai fasilitator dalam proses pembelajaran. Menurut Trianto Ibnu Badar Al Tabany (2015:7) pemahaman konsep dalam proses pembelajaran sangat mempengaruhi sikap, keputusan dan caracara peserta didik memecahkan masalah. Guru sebagai pemegang kendali penuh atas iklim dalam suasana pembelajaran, harus mampu menciptakan ruang belajar dimana peserta didik menjadi aktif dan bertanggung jawab terhadap proses belajarnya. Guru dituntut harus memiliki kemampuan tidak hanya menguasai sejumlah materi pembelajaran, tetapi juga terampil dalam menggunakan pendekatan pembelajaran yang tepat sesuai dengan karakteristik mata pelajaran fisika.
Berbagai pendekatan pembelajaran dapat diterapkan dalam proses pembelajaran fisika. Salah satu pendekatan yang dapat digunakan oleh guru adalah pendekatan kontesktual. Menurut Nurhadi (dalam M. Hosnan, 2016:267), pendekatan kontekstual adalah konsep belajar yang mengaitkan antara materi yang diajarkan dengan situasi nyata peserta didik. Konsep belajar tersebut mendorong peserta didik membuat hubungan antara pengetahuan yang diperoleh dengan penerapannya dalam kehidupan peserta didik.

Pendekatan kontekstual sangat membantu peserta didik dan guru dalam proses pembelajaran. Menurut Trianto Ibnu Badar Al Tabany (2015: 141) penyajian materi pelajaran dengan kontekstual keseharian peserta didik akan menghasilkan dasar-dasar pengetahuan yang mendalam dan mudah dipahami. Peserta didik akan mampu mandiri dalam menggunakan pengetahuannya untuk menyelesaikan masalah-masalah yang baru dan belum pernah dihadapinya. Selanjutnya menurut Cecep 2007 (dalam Trianto Ibnu Badar Al Tabany, 2015:142) teori pendekatan kontekstual berfokus pada lingkungan belajar yang beragam di antaranya ruang kelas, laboratorium, tempat bekerja dan tempat-tempat lainnya.

$$
\text { Pembelajaran menggunakan }
$$
pendekatan kontekstual sangat dipengaruhi pengelolaan sumber belajar. Sumber belajar yang tepat dapat meningkatkan 
belajar yang tepat dapat meningkatkan prestasi belajar peserta didik. Sumber belajar disajikan sedemikian rupa, sehingga menjadi bahan ajar yang membantu peserta didik dalam proses pembelajaran. Pengembangan bahan ajar disesuaikan dengan kompetensi dasar, kebutuhan peserta didik, dan lingkungan sosial, sehingga dapat membantu peserta didik dalam memperoleh alternatif bahan belajar. Bahan belajar tersebut dapat berupa bahan non cetak seperti video dan multimedia pembelajaran serta dapat berupa bahan cetak seperti buku, dan modul.

Modul sebagai salah satu alternatif bahan ajar yang dapat membantu peserta didik dalam proses pembelajaran. Modul dapat disusun sendiri oleh guru diharapkan dapat meningkatkan prestasi belajar. Selain itu materi yang disampaikan oleh guru melalui modul dapat disesuaikan dengan kebutuhan peserta didik dan tuntutan kurikulum yang berlaku.

Hasil observasi di SMA Negeri 5 Jayapura pada bulan Maret sampai Mei 2018 menunjukkan bahwa materi dinamika partikel di kelas X masih kurang maksimal. Berdasarkan data PAMER UN yang dikeluarkan oleh PUSPENDIK dan hasil analisis ujian semester, daya serap rata-rata peserta didik SMA Negeri 5 Jayapura materi dinamika partikel kurang dari lima puluh persen. Laporan hasil ujian nasional menunjukkan bahwa tahun 2016 daya serap peserta didik pada materi dinamika partikel 37,01 persen dan pada tahun 2017 daya serap peserta didik 29,17 persen serta hasil analisis ujian semester tahun pelajaran 2017/ 2019 daya serap rata-rata peserta didik kelas $X$ di SMA Negeri 5 jayapura untuk materi dinamika partikel 28,22 Persen. Daya serap tersebut menggambarkan bahwa kriteria ketuntasan minimal (KKM) belum tercapai pada materi dinamika. Hal mengindikasikan bahwa prestasi belajar peserta didik pada materi dinamika partikel dalam kategori rendah.

Satu upaya yang dapat dilakukan untuk meningkatkan pemahaman peserta didik terhadap materi dinamika partikel adalah mengembangkan modul pembelajaran fisika dengan pendekatan kontekstual. Menurut Trianto Ibnu Badar Al Tabany (2015: 141) penyajian materi pelajaran dengan kontekstual keseharian peserta didik akan menghasilkan dasardasar pengetahuan yang mendalam dan mudah dipahami. Peserta didik akan mampu mandiri dalam menggunakan pengetahuannya untuk menyelesaikan masalah-masalah yang baru dan belum pernah dihadapinya. Menurut hasil penelitian Nurcahya (2014) modul pembelajaran IPA dengan pendekatan kontekstual efektif meningkatkan hasil belajar peserta didik. Fisika sebagai salah satu bagian dari rumpun mata pelajaran IPA sehingga modul dengan pendekatan 
kontekstual sangat relevan digunakan dalam pembelajaran.

\section{METODE PENELITIAN}

Rancangan penelitian yang digunakan adalah penelitian dan pengembangan (Research and

Deveopement $/ R \& D$ ) dan menggunakan rancangan one group pre test post test desaign. Metode $\mathrm{R} \& \mathrm{D}$ adalah metode penelitian yang digunakan untuk menghasilkan produk dan menguji keefektifan produk tersebut (Sugiyono, 2015: 28).

Prosedur penelitian ini dibagi menjadi tiga tahap yaitu pengumpulan informasi, rancangan produk berupa modul fisika kontekstual, dan tahap ketiga pengembangan modul fisika.

\section{Uji Coba Produk}

Uji coba produk dilaksanakan di SMA Negeri 5 Jayapura dengan populasi target Kelas $\mathrm{X}$ semester dua tahun pelajaran 2018/ 2019. Subjek uji coba di lapangan menggunakan kelas X IPA 3 yang berjumlah 32 orang peserta didik.

\section{Variabel Penelitian}

Variabel penelitian menggunakan variabel bebas dan variabel terikat. Variabel bebas dalam penelitian ini adalah pembelajaran menggunakan modul fisika berbasis kontekstual materi dinamika partikel sedangkan variabel terikatnya adalah prestasi belajar peserta didik menggunakan modul fisika berbasis kontekstual materi dinamika partikel.

\section{Desain Uji Coba}

Modul yang di kembangkan melewati beberapa pengujian yaitu: 1) uji validitas dan reliabilitas instrumen penelitian, 2) uji kelayakan modul, dan 3) uji n-Gain. Uji validitas dan reliabilitas pada instrumen angket respon peserta didik dan instrumen tes menggunakan program SPP yakni analisis korelasi (Pearson Correlation) dan reliabilitas model Alpha Cronbach's. Kelayakan modul fisika yang telah dikembangkan peneliti menggunakan analisis deskriptif persentase pada instrumen pengumpulan data berupa angket validasi materi, validasi materi, respon peserta didik. Uji n-Gain pada hasil pre test post test peserta didik untuk mengetahui tingkat penguasaan materi yang telah diberikan pada setiap pertemuan.

\section{HASIL DAN PEMBAHASAN}

Penelitian pengembangan ini menghasilkan produk pembelajaran berupa modul. Tahap pengembangan modul fisika berbasis kontekstual materi dinamika partikel adalah tahap pengumpulan informasi, tahap desain produk berupa modul fisika kontekstual, dan tahap pengembangan modul fisika kontekstual.Modul fisika berbasis kontekstual materi dinamika partikel kelas $\mathrm{X}$ terdiri atas 3 (tiga) komponen yaitu sebagai berikut:

1. Bagian pendahuluan yang terdiri dari latar belakang, tujuan, kompetensi 
dasar, ruang lingkup, dan cara penggunaan modul.

2. Bagian isi terdiri dari indikator pencapaian kompetensi, tujuan pembelajaran, uraian materi, kegiatan pembelajaran, latihan soal, rangkuman, umpan balik dan tindak lanjut, tes uji kompetensi dan kunci jawaban.

3. Bagian penutup yang terdiri dari glosarium dan daftar pustaka.

Kelayakan modul pembelajaran fisika berbasis kontekstual dapat dilihat dari validasi materi, validasi media, respon guru mata pelajaran dan peserta didik. Kriteria kelayakan pada modul mengacu pada referensi Elice dalam Subiyanto dan Tiurlina Siregar, 2018 pada tabel 1 sebagai berikut:

Tabel 1 Kriteria kelayakan modul

\begin{tabular}{|c|c|l|}
\hline Presentase & Kualifikasi & \multicolumn{1}{|c|}{ Keterangan } \\
\hline $80 \% \leq \mathrm{p} \leq 100 \%$ & Layak & $\begin{array}{l}\text { Sangat baik, tidak perlu } \\
\text { direvisi }\end{array}$ \\
\hline $60 \% \leq \mathrm{p} \leq 79 \%$ & $\begin{array}{c}\text { Cukup } \\
\text { layak }\end{array}$ & $\begin{array}{l}\text { Baik, perlu direvisi } \\
\text { sebagian }\end{array}$ \\
\hline $50 \% \leq \mathrm{p} \leq 59 \%$ & $\begin{array}{l}\text { Kurang } \\
\text { layak }\end{array}$ & $\begin{array}{l}\text { Kurang baik, revisi } \\
\text { sebagian dan pengkajian } \\
\text { ulang isi materi }\end{array}$ \\
\hline $40 \% \leq \mathrm{p} \leq 49 \%$ & Tidak layak & $\begin{array}{l}\text { Tidak baik, revisi total dan } \\
\text { pengkajian ulang isi materi }\end{array}$ \\
\hline $\mathrm{p}<40 \%$ & $\begin{array}{c}\text { Sangat } \\
\text { tidak layak }\end{array}$ & $\begin{array}{l}\text { Sangat tidak baik, revisi } \\
\text { total dan pengkajian ulang } \\
\text { isi materi }\end{array}$ \\
\hline
\end{tabular}

Hasil uji validasi materi pada gambar 1

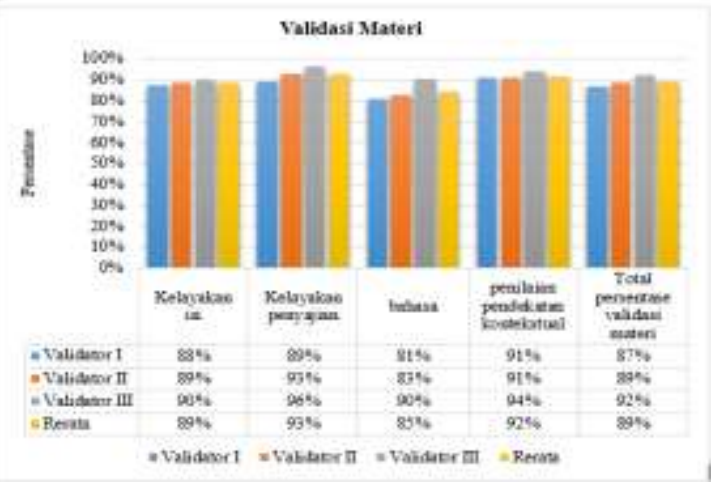

Gambar 1. Diagram batang validasi materi
Gambar 1 hasil validasi materi diperoleh rerata $89 \%$ dengan kategori layak. Beberapa hal yang perlu diperbaiki antara lain adalah gambar yang ada di modul sebaiknya kontekstual khas Papua, contoh-contoh soal sebaiknya tidak terlalu banyak, lebih akurat dan kontekstual. Hasil validasi media pada gambar 2 .

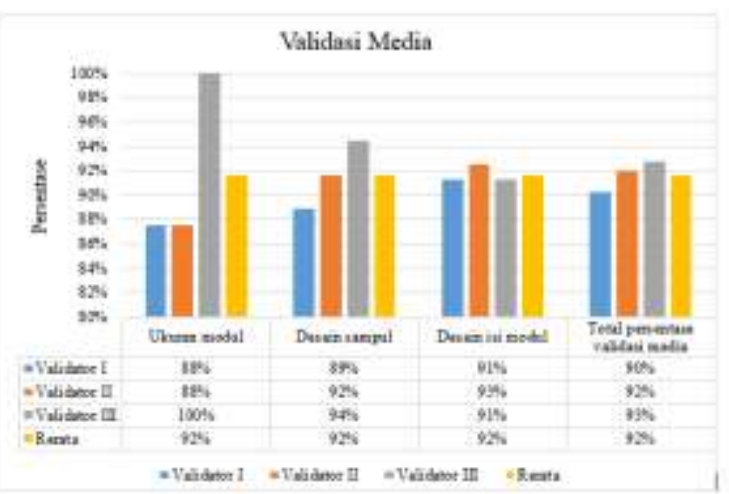

Gambar 2. Diagram batang validasi media

Gambar 2 hasil validasi media diperoleh rerata $92 \%$ kategori layak. Hal hal yang perlu direvisi adalah tata bahasa, penjelasan modul lebih diperjelas, penulisan spasi dan huruf perlu diperbaiki.

Berdasarkan hasil wawancara oleh 2 (guru) mata pelajaran fisika keduanya memberi respon baik, dan sangat setuju dengan adanya modul fisika berbasis kontekstual materi dinamika partikel. Hasil wawancara tersebut memberikan informasi bahwa pada umumnya peserta didik belajar menggunakan buku cetak yang disediakan oleh sekolah dengan jumlah yang sangat terbatas. Buku cetak yang tersedia saat ini sebatas penyedia informasi untuk membantu peserta didik memahami konsep-konsep fisika. Sementara Budi Kustoro (2016: 27) berpendapat bahwa 
tujuan pembelajaran di sekolah sebaiknya memfasilitasi peserta didik untuk membangun dan mengembangkan diri peserta didik pada segala aspek yaitu: aspek kognitif, afektif, psikomotorik, emosional, dan spiritual. Kelima aspek perkembangan individu tersebut dapat dicapai dengan sumber belajar inovatif. Sumber belajar yang inovatif yang dimaksud adalah modul dengan menggunakan pendekatan kontekstual.

Modul fisika dengan pendekatan kontekstual menyajikan pembelajaran dalam konteks autentik, dimana penilaian proses pembelajaran meliputi aspek kognitif, afektif, dan psikomotorik. Proses pembelajaran menekankan terciptanya masyarakat belajar melalui forum diskusi kelompok antara peserta didik maupun peserta didik dengan guru. Melalui masyarakat belajar aspek emosional dan spiritual peserta didik akan berkembang dengan baik. Pemodelan dalam kegiatan pembelajaran melalui metode demonstrasi dalam modul memudahkan peserta didik dalam memahami konsep jika dibandingkan dengan metode ceramah. Hal ini sesuai dengan pendapat $M$. Hosnan (2014: 272) yang mengatakan bahwa dalam kegiatan pemodelan melalui contohcontoh yang baik akan berguna bagi peserta didik agar dapat terhindar dari pembelajaran yang bersifat teoritis semata.

Melalui hasil validasi pakar, tanggapan guru dan respon peserta didik dapat disimpulkan bahwa modul fisika berbasis kontekstual materi dinamika partikel diperoleh total rata-rata uji kelayakan modul sebesar 89 kategori layak. Tanggapan positif diperoleh dari peserta didik terhadap modul ini dikarenakan modul memiliki beberapa keunggulan yakni sajian materi muda dipahami oleh peserta didik melalui bahasa yang sederhana, dilengkapi gambar kontekstual sesuai dengan kehidupan sehari-hari dan aktivitas pembelajaran yang menyenangkan. Tanggapan positif juga diperoleh salah satu guru mata pelajaran fisika yang berpendapat bahwa modul fisika kontekstual sangat menarik dan dapat memotivasi peserta didik dan guru untuk meningkatkan kualitas pembelajaran. Hal ini sejalan dengan pendapat dari Widya Oktovani, Gunawan dan Sutrio (2017) tentang bahan ajar fisika kontekstual adalah bahan ajar yang memuat contoh-contoh kontekstual fisika yang sesuai dengan kehidupan nyata peserta didik dan pendapat Nurcahya dan Basa T. Rumahorbo (2016) yang mengatakan bahwa sajian materi dengan bahasa sederhana dan komunikatif pada modul pembelajaran IPA pendekatan kontekstual memudahkan peserta didik untuk belajar mandiri.

Hasil uji skala luas untuk melihat peningkatan prestasi belajar peserta didik setelah menggunakan modul diberikan tes yang dilaksanakan selama 3 kali 
pertemuan. Setiap pertemuan di awali dengan pre test dan diakhiri dengan post test.Instrumen tes yang diujikan berjumlah 25 soal pilihan ganda yang telah dilakukan uji validitas dan reliabilitas dengan SPSS 22. Uji validitas menggunakan analisis korelasi pada kolom person correlation dengan ketentuan instrumen dikatakan valid jika nilai pada kolom tersebut lebih besar atau sama dengan 0,3 (Sugiyono, 2015: 185) sedangkan uji reliabilitas menggunakan statistik Cronbanch's alpha dengan ketentuan instrumen reliabel jika memiliki nilai alfa lebih besar atau sama dengan 0,6 .

Hasil pengujian skala luas pada gambar 3 menampilkan hasil pre test dan posttest peserta didik 3 pertemuan.

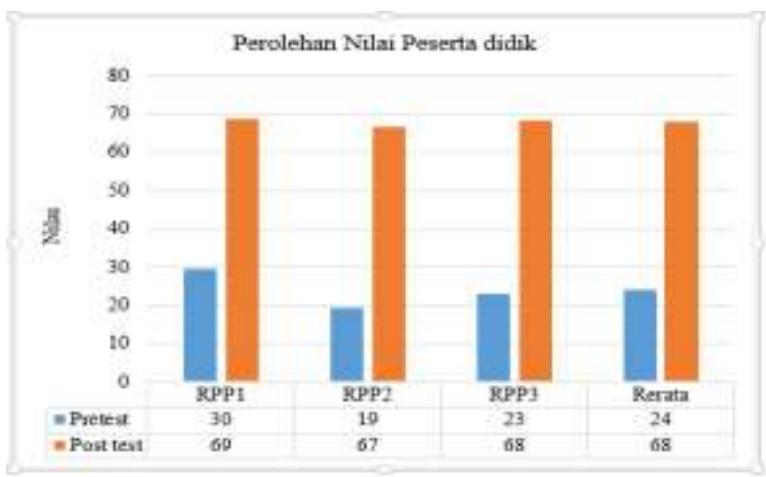

Gambar 3. Diagram batang Perolehan nilai rata-rata kelas peserta didik

Rerata nilai post test yang diperoleh pada tiga pertemuan dengan modul fisika berbasis kontekstual adalah 68 (gambar 3). Rata-rata tersebut sudah di atas nilai kriteria ketuntasan minimum (KKM) yang di tetapkan yaitu 65. Pada RPP 2 dan RPP 3 mengalami penurunan karena karena topik pada RPP 2 dan RPP 3 jauh lebih kompleks jika dibandingkan dengan RPP 1.

Hasil uji n-Gain digunakan untuk mengetahui tingkat penguasaan konsep materi dinamika partikel dengan menggunakan modul fisika berbasis kontekstual. Uji n-Gain pada penelitian ini menggunakan referensi kriteria $\mathrm{n}$-Gain oleh Hake R, 1999 pada tabel 2 sebagai berikut:

Tabel 2. Hasil uji n-Gain

\begin{tabular}{|c|c|}
\hline $\begin{array}{c}\text { Nilai Indeks } \\
\text { Gain }\end{array}$ & Kategori \\
\hline $\mathrm{g}>0,7$ & tinggi \\
\hline $0,3 \leq g \leq 0,7$ & sedang \\
\hline $\mathrm{g}<0,3$ & rendah \\
\hline
\end{tabular}

Hasil Uji n-Gain penelitian ini pada tabel 3 .

Tabel 3. Hasil uji n-Gain

\begin{tabular}{|c|c|c|c|c|c|}
\hline Pertemuan & Kategori & Jumlah & Persentase & $\begin{array}{c}\text { n-Gain } \\
\text { Rata- } \\
\text { rata }\end{array}$ & Kategori \\
\hline \multirow{3}{*}{ RPP1 } & Rendah & 2 & $6,25 \%$ & \multirow{3}{*}{0,52} & \multirow{3}{*}{ Sedang } \\
\hline & Sedang & 26 & $81,25 \%$ & & \\
\hline & Tinggi & 4 & $12,50 \%$ & & \\
\hline \multirow{3}{*}{ RPP2 } & Rendah & 2 & $6,25 \%$ & \multirow{3}{*}{0,58} & \multirow{3}{*}{ Sedang } \\
\hline & Sedang & 26 & $81,25 \%$ & & \\
\hline & Tinggi & 4 & $12,50 \%$ & & \\
\hline \multirow{3}{*}{ RPP3 } & Rendah & 2 & $6,25 \%$ & \multirow{3}{*}{0,61} & \multirow{3}{*}{ Sedang } \\
\hline & Sedang & 21 & $65,63 \%$ & & \\
\hline & Tinggi & 9 & $28,13 \%$ & & \\
\hline \multicolumn{4}{|c|}{ Rata-rata } & 0,57 & Sedang \\
\hline
\end{tabular}

Berdasarkan tabel 3 bahwa pada RPP 1, RPP 2, dan RPP 3. Hasil uji n-Gain rata-rata pada RPP 1 sebesar 0,52 dengan kategori sedang. Hasil Uji n-Gain pada tabel 1 menunjukkan bahwa nilai n-gain mengalami peningkatan dari RPP 1 , RPP 2 dan RPP 3. Nilai n-Gain tertinggi diperoleh dari RPP 3, hal ini menandakan bahwa peserta didik yang awalnya kurang 
memahami materi dinamika partikel setelah diberi pembelajaran dengan modul berbasis kontekstual efektif meningkatkan prestasi belajar fisika peserta didik. Hal ini sejalan dengan pendapat dari Nurcahya (2016) yang menyatakan bahwa penggunaan modul berbasis kontekstual sebagai sumber belajar efektif meningkatkan prestasi belajar peserta didik secara signifikan.

Penelitian pengembangan dengan produk pembelajaran fisika berbasis kontekstual materi dinamika partikel untuk meningkatkan prestasi belajar peserta didik kelas X SMA Negeri 5 Jayapura ini memiliki kelebihan antara lain:

a. Modul Fisika pertama di SMA Negeri 5 jayapura yang pertama berbasis kontekstual.

b. Belajar dengan menggunakan modul lebih menarik, karena materi disajikan dengan ilustrasi dan contoh yang bersifat kontekstual.

c. Modul ini dilengkapi dengan panduan penggunaan modul sehingga memudahkan peserta didik untuk belajar mandiri.

d. Modul ini dilengkapi dengan aktivitas pembelajaran, rangkuman, latihan soal, dan refleksi sehingga lebih efektif dan efisien.

e. Penggunaan bahasa sederhana dalam modul sehingga mudah dipahami oleh peserta didik.
Kekurangan modul fisika berbasis kontekstual materi dinamika partikel antara lain:

a. Pengembangan modul membutuhkan biaya relatif mahal dan waktu lama. Pengembangan modul membutuhkan perencanaan matang, memerlukan kerjasam tim antara penyusun, memerlukan dukungan fasilitas, media, sumber dan lainnya.

b. Pengembangan modul membutuhkan membutuhkan keahlian tertentu, sehingga keberhasilan modul dalam meningkatkan prestasi belajar peserta didik sangat bergantung pada penyusunnya.

c. Tidak semua peserta didik dapat belajar mandiri, oleh karena itu pembelajaran menggunakan modul membutuhkan ketekunan dan kedisiplinan tinggi dari guru untuk memantau proses belajar peserta didik sehingga tujuan pembelajaran dapat tercapai secara maksimal.

\section{SIMPULAN DAN SARAN}

\section{SIMPULAN}

Modul fisika berbasis kontekstual materi dinamika partikel layak digunakan sebagai modul pembelajaran sesuai data hasil validasi materi dengan rerata sebesar 89\% kategori layak, validasi media dengan rerata sebesar 92\% kategori layak, kecil respon peserta didik dengan rerata sebesar $88 \%$ kategori layak, uji skala luas respon peserta didik dengan rerata $88 \%$ kategori 
layak dan rerata persentase sebesar $89 \%$ kategori layak. Peningkatan prestasi belajar fisika peserta didik menggunakan modul fisika berbasis kontekstual materi dinamika partikel dilihat dari hasil RPP1 dengan nGain rata-rata sebesar 0,52 kategori sedang, RPP2 dengan $\mathrm{n}$-Gain rata-rata sebesar 0,58 kategori sedang, RPP3 dengan n-Gain rata-rata sebesar 0,61 kategori sedang, dan $\mathrm{n}$-Gain rata-rata sebesar 0,57 kategori sedang, sehingga dapat dinyatakan bahwa terdapat peningkatan prestasi belajar fisika dengan menggunakan modul berbasis kontekstual.

\section{SARAN}

Modul fisika berbasis kontekstual materi dinamika partikel dapat digunakan sebagai bahan ajar bagi guru dengan cara memperhatikan alokasi waktu pelajaran agar pembelajaran berjalan lancar dan diperoleh prestasi belajar maksimal.

\section{UCAPAN TERIMAKASIH}

Terimakasih kami ucapakan kepada Kepala Sekolah SMA Negeri 5 Jayapura dan Ketua Program Studi Magister pendidikan IPA untuk kerjasamanya dalam memfasilitasi penelitian ini sehingga dapat dilaksanakan.

\section{DAFTAR PUSTAKA}

Hake R, 1999, Analyzing Change/Gain Score, Indiana, Indiana University;

I Wayan Santyana, 2015, Asesmen dan Evaluasi Pembelajaran Fisika, Jakarta, Graha Ilmu;

M. Hosnan, 2016, Pendekatan saintifik dan Konstekstual dalam Pembelajaran Abad 21, Bogor, Ghalia Indonesia;

Nurcahya dan Basa T. Rumahorbo, 2016, Pengembangan Modul IPA dengan Pendekatan Kontekstual pada Topik Objek Kajian IPA dan Pengamatannya di Kelas VII SMP Muhammadiyah Abepura. Jurnal Ilmu Pendidikan Indonesia, Vol 4 (3) 35-42;

Subiyanto dan Siregar T., 2018, Pengembangan Modul Pembelajaran Kimia pada Materi Sistem Periodik Unsur Berbasis Kearifan Lokal Papua Peserta Didik Kelas X SMA Negeri 4 Jayapura, Jurnal Ilmu Pendidikan Indonesia, Vol 6 (3) 7182;

Sugiyono, 2015, Metode Penelitian dan Pengembangan Research and Development, Bandung, Alfabeta;

Trianto Ibnu Badar Al-tabany, 2015, Mendesain Model Pembelajaran Inovatif, Progresif dan Kontekstual, Jakarta Prenada media Group. 